\title{
Choosing your own boss: Variations of representation foci in mixed electoral systems
}

\author{
Mihail Chiru ${ }^{1}$ and Zsolt Enyedi ${ }^{2}$
}

\begin{abstract}
MPs are privileged agents. They can choose whom to regard as their principal: the entire nation, a particular electoral district or a political party. Focusing on two countries with mixed electoral systems, Romania and Hungary, the article documents the dominance of the electoral logic of role-formation over the constraints of legislative organization and the influence of socialization. The focus of representation is found to be only modestly influenced by the degree of the embeddedness of MPs in political structures and hierarchies. The association of the seat with a particular territorial unit, on the other hand, has a robust effect even when this association originates in the political environment and not in formal rules. Finally, the psychological effect of losing a Single Member District is also found to influence how MPs perceives their representative role.
\end{abstract}

Keywords: representation focus, electoral logic, parliamentary logic, mixed electoral systems, Hungary, Romania

Journal of Legislative Studies

\footnotetext{
${ }^{1}$ Oxford School of Global and Area Studies, University of Oxford. Email address: mihail.chiru@area.ox.ac.uk, phone: 07518407676; postal address: 11 Bevington Road, UK, OX2 6NB, corresponding author.

${ }^{2}$ Central European University Budapest, enyedizs@ ceu.hu, Nador u. 9, 1051, Budapest.
} 


\section{Introduction: questions and cases}

The members of parliaments are free to interpret whose representatives they are. The range of options is wide and constantly evolving. But traditionally most of the MPs consider themselves primarily either as ambassadors of a geographically bounded community, as representatives of a party or as politicians charged with the task of looking after the entire nation. Serving the party, the country or the electoral district are not necessarily mutually exclusive goals, but giving equal priority to each of them is rarely feasible.

The present article investigates the relationship between the foci of representation and a selected list of factors, including the size of the party, the rank of the politicians, their local embeddedness and the length of their party membership, but for the analysis the electoral rules and the incentives created by them take the central stage. By focusing on these factors we test and amend claims developed by a growing body of institutionalist literature ${ }^{i}$. More specifically, the article relates to some recent projects that analyzed mixed electoral systems ${ }^{\mathrm{ii}}$.

The advantage of focusing on systems that have multiple electoral channels is that the analysis can hold constant many potentially confounding variables, providing the researcher with a convenient quasi-experimental design. The logic of territorial- and party-based electoral systems is not perfectly replicated within mixed systems since the different electoral channels interact in affecting the strategic considerations of voters, parties and candidates (Ferrara et al 2005), but exactly because of the existence of this 'contamination effect' mixed systems present a demanding test for the claims concerning the differences between the differently constructed parliamentary mandates

Mixed systems specifically allow for the comparison between representatives acting according to list- or district-logic. Most evidently the two groups can be distinguished by the nature of their seats, i.e. the way how they have been elected. Different types of seats are associated with differences in campaign experience and with different expectations from the environment, from fellow politicians and voters. One of the central questions of the article is whether the experiences collected as candidates overshadow the motivations stemming from holding different kind of seats. In other words, do the party-list MPs differ from the district MPs because they have different seats or because they were different candidates? Furthermore, even if the different orientation of MPs elected according to different rules is documented, one may still wonder about the nature of the causal mechanism. Are, for example, the differences due to formal procedures or could a simple informal association between an MP and a geographically bounded constituency generate distinct principal-agent perceptions?

In order to answer these questions the article examines two countries, Hungary and Romania, that are similar to the extent that they employ mixed member electoral systems but differ in the degree to which the type of candidacy and the nature of seat are institutionalized. By focusing on these cases two different logics of mixing majoritarian and proportional rules can be investigated. In Hungary some candidates are exclusively list-candidates while others are present in both channels ${ }^{\mathrm{iii}}$. In Romania all politicians run as SMD candidates, and only the logic of seat allocation divides them into two groups. The law assigns a district to all MPs, the district where they were candidates, but only the candidates receiving the absolute majority of votes gain the seat directly. The others win the seat thanks to the aggregation of party votes at county and national levels (Chiru and Ciobanu 2009). One can become the MP of a particular district 
receiving many times fewer votes than his competitor. There are no legally defined differences between the seats, but the political environment treats those who actually obtained the support of the district differently from those who have not. Therefore the difference between more and less district-bound MPs is relevant also in the Romanian case. But it is important to keep in mind that the division of the MPs into more or less district-bound categories materializes in the two countries in different forms.

The characteristics of the chosen cases also allow us to differentiate between the parliamentary logic, which implies that an MP should think and behave according to the nature of the seat, and the electoral logic, which implies that the focus of representation should depend on the nature of the campaign, particularly as far as dependence on the nominating party is concerned. While many politicians are aware during the campaigns of what sort of seats they may end up with, some are bound to be surprised once all the votes are counted. In Hungary politicians may consider themselves primarily as SMD candidates, yet end up with a list seat. In Romania a candidate may be confident enough to plan an outright victory of the district, and yet may finish holding the seat simply due to the popularity of his party in the region or nation-wide. The contrast between the two groups can help us to discern which of the above listed two logics is more powerful.

The empirical material used in the analysis is based on two surveys conducted in 2010. In Hungary 241 MPs were interviewed, $62.7 \%$ of all the deputies, as part of the Hungarian Candidate Study (Enyedi 2010). The Romanian parliamentary sample (Stefan 2010) is based on self-administered questionnaires: 170 members of the Chamber of Deputies (50.6\%) participated in the survey. ${ }^{\text {iv }}$ As it can be seen from the two tables in Appendix 2 the completed samples are highly representative of the MP populations with respect to incumbency, gender and party affiliation. The content of the two surveys overlapped but they also differed in many regards. The Hungarian study was conducted right after the election and contained a long battery of questions on campaigning. ${ }^{\mathrm{v}}$ The Romanian study was a mid-term study, asking a number of questions on the practice of representation, including the emphasis on constituency work. The two studies complement each other: in the Hungarian case we can find out whether the style of campaigns and the incentives stemming from the electoral arena shape the embraced roles, the Romanian data-set allows to investigate whether the different roles imply also differences in the actual parliamentary work.

At the time of the surveys the Romanian party system was characterized by the dominance of two large parties, PSD (Social Democratic Party) and PDL (Democratic Liberal Party), closely followed by a mid-sized party, the PNL (National Liberal Party). The premiership and the presidency were in the hands of PDL, but the government commanded only a narrow majority. In contrast to Romania, Hungary was undergoing a major party system transformation in 2010. The previously ruling MSZP (Hungarian Socialist Party) suffered a humiliating defeat at the parliamentary election, the right-wing Fidesz won two thirds of the seats, and the radical right Jobbik gained almost as much support as MSZP did (Batory 2010). Virtually all single member seats were taken by Fidesz and therefore the analysis of SMD-representatives will actually mean an analysis of Fidesz MPs. ${ }^{\text {vi }}$

The first section of the article outlines those theoretical models of role formation that informed our research and presents the main variables and hypotheses associated with them. The second section includes a brief validation of our dependent variable. Next, we present and discuss the 
results of the multivariate analyses. The conclusions synthesize the main findings and their implications. The principal aim of this paper is to grasp the electoral logic of role formation, as a phenomenon that is distinct from socialization and the constraints of political hierarchies.

\section{Theoretical framework and main variables}

MPs can consider themselves as being agents of an indefinite number of principals, including gods, oligarchs or foreign countries, but the literature of the 'focus of representation' classically distinguishes between MPs oriented towards district, party, specific social group, or entire nation (or 'all citizens in the country'). The focus of representation is seen as a major aspect of the representative roles, alongside the style of representation.

When it first appeared in political science, the legislative role theory was part of the structuralfunctionalist paradigm. As a consequence, its conceptual frame applied mainly to entire legislative bodies and largely ignored the preferences and choices of individuals. The theory had a prominent normative dimension: roles were seen as norms of conduct to be internalized by all actors. This internalization would happen primarily through socialization (Wahlke et al, 1962; Saalfeld and Müller, 1997, pp. 2-9).

The concept of purposive roles (Wahlke et al, 1962, p. 12; Jewell, 1983) constituted a shift away from this paradigm as it acknowledged the relevance of the MPs' subjective understandings. The idea was developed into either sociological or rational choice directions. Representing the first strand of research, Searing (1994) uncovered with the help of in-depth interviews the actual roles representatives were undertaking while in Westminster, in the Whitehall and in the constituencies. For Searing it was crucial 'to free' politicians from the abstract categories imposed on them by researchers and to reveal the most salient personal reasons behind role choice. Searing argued that backbench MPs have particularly large freedom in choosing a role since they are unconstrained by the duties and normative expectations that come with parliamentary or ministerial office.

Strøm (1997) considered the claim that roles are bounded by the interaction between institutional constraints and individual preferences valid, but, in line with the dominant frame of rational choice neo-institutionalism, emphasized the teleological and strategic components of the attitudes. Accordingly, roles are strategies chosen by politicians to reach the predefined goals of re-selection, re-election, party office and parliamentary office, and they are shaped by institutional rules (Strøm, 1997, pp. 162-163).

All the frameworks discussed so far, even Strøm's with its focus on re-election and on the underpinning institutions, ignore a number of factors relevant for the electoral process. The type of candidature of the MP, the manner in which he campaigned and finally, the outcome of the election, may all contribute to role formation. The present article takes these factors into consideration in the course of explaining the variance in the focus of representation. Style, i.e. how independent-minded the representatives are vis-à-vis their voters and their parties, will also be included into the analysis but only ${ }^{\mathrm{vii}}$ as part of the interpretation of the answers given to the focus question.

The dependent variable is captured by the survey question asking whether the MP primarily represents his own voters in the constituency, all citizens in the constituency, the party electorate 
at large, specific social groups or all the citizens in the country. ${ }^{\text {viii }}$ The question did not allow the respondents to choose more than one category. Since only few respondents opted for the 'own voters in the constituency' and the 'specific social group' categories the former was merged with the 'all citizens in the constituency' (to produce the category 'constituency'), while the latter was left out from the analysis.

The principal independent variables are related to the electoral context. The literature is divided as far as the role of electoral systems is concerned. The majority of the studies (Carey and Shugart, 1995; Crisp et al, 2004) assume or document a link between the way the MPs were elected, meaning whether they gained a territorially bounded seat or a party list seat and how they think about their role as representatives. A significant minority finds no such link (Bogdanor, 1985; Mezey, 1979). Those who report the influence of electoral rules most typically conclude that SMD-based elections strengthen the constituency focus - that is, choosing the electoral district as one's principal (Carey and Shugart, 1995; Katz, 1997). SMD candidates have also been shown to make more contact with citizens (Curtice and Shively, 2000), although Studlar and McAllister (1996) argued that the constituency work is shaped primarily by role perception, and the latter does not depend on the route to the legislature.

The obvious problem of contrasting attitudes of MPs operating under various electoral rules is that the differences can be attributed to a host of factors besides the nature of the seat. One way to solve the problem is to examine mixed systems and contrast the list-MPs with the district MPs, exploiting the quasi-experimental nature of such cases (Shugart and Wattenberg, 2001; Zittel and Gschwend, 2008). The typical finding of such studies is that in mixed systems the SMD candidate will be more constituency-oriented (Gallagher and Holliday, 2003; Bawn and Thies, 2003).

The rationale for which one expects a difference between district-bound and non-district-bound MPs is almost taken for granted in the literature. But in fact there can be multiple logics at work. On the one hand different types of seats come with different expectations from the environment, from fellow politicians, party leaders and voters. The "type of seat" variable above is supposed to tap these expectations. The environmental expectations emerge once one occupies his seat. The phenomenon follows a parliamentary logic to the extent that it entails a division of labor between SMD and list politicians within the parliaments.

But electoral rules shape not only the type of seat but also the type of candidacy. The role of parties in controlling the nomination of the candidates and in supporting their campaigns differs across electoral channels, with the result that candidates experience campaigns differently. Following this logic Lundberg (2002) argued that roles depend on where a candidate ran and where he plans to run, and not where he won the seat.

Under certain electoral rules candidates are left largely on their own to win the seat, while in the opposite extreme a candidate's success depends entirely on the party's success. In systems where 'dual candidacy' exists, locally popular candidates may think of themselves as possible ambassadors of their district, while weaker ones have this option less, and therefore may turn to the party as their only savior. Accordingly, Zittel (2009) found that hopeless candidates are in general more party- than district-focused.

Once the MPs occupy their seat, they become part of a large-scale and influential organization, and it is reasonable to assume that their status within the Parliament will shape how they think 
about their representative role. First, the work-experience of high ranking office-holders is specific. They deal with (inter)national issues and parliamentary procedures and therefore they must have less time to spend on district-related matters. Their chance to get leading nonparliamentary political roles is also higher. In the arena-type legislatures (and our cases belong to his category, cf. Olson and Norton, 2007) receiving a parliamentary office is an honor bestowed on the politician by the party leaders, seniority being of secondary relevance. As a result, the expectation is that high status MPs will see themselves as party representatives. This tendency may be somewhat tempered by the fact that higher office may also give these MPs more possibility to channel resources to their district and therefore they may be much sought after actors in local politics as well.

Similar logic applies to the status within the party. In this case identification with the party has an even more straightforward rationale, and the time-related constraints of local activities together with the possibility of gaining high national offices like prime-ministership, should apply even more.

High party office may reflect the degree of socialization within the party (Zittel, 2009; Heitshusen et al, 2005), but the length of party membership is probably an even more accurate indicator of socialization. Newly co-opted members may have less deep attachment to the party and thus may concentrate on representing the interest of a particular constituency or of all the citizens in the country. In the rather different context of the European Parliament elections, party membership duration proved to enhance the party focus of the delegates (Weßels and Giebler, 2011, p. 17). On the other hand, the opposite relationship cannot be ruled out either: newcomers may feel particularly under pressure to prove their loyalty to the party.

Following the logic of the factors listed above, position in local politics (Norris, 1997, pp. 33-34) and local origin (Tavits, 2010) was also shown to have an impact on representative roles. Those who cumulate the parliamentary mandate and a local office (e.g. mayor, as it is possible in Hungary) continue to be exposed to local demands and expectations. Moreover, previous local politics experience can have a similar effect. Thus, spending years dealing with local affairs may socialize the candidates into a district-focus. One would expect MPs who lack local politics experience to eschew the district-principal and embrace the party-logic.

Next to the status in party- and institutional hierarchies, the ideological distance between the MPs and their party may also influence their role perceptions (Zittel and Gschwend, 2008). If MPs sees considerable distance between themselves and the party mainstream they may be reluctant to regard the party as their principal. On the other hand, genuinely district-focused candidates may have very little interest in ideological matters. Therefore, when they are asked about their own left-right position they may simply reproduce the position of the party, creating thereby a positive correlation between district-focus and ideological proximity.

Finally, in larger parliamentary parties there is room for more division of labor (Heidar and Koole, 2000). As a result, backbenchers will have more time to concentrate on the needs of their constituencies than their counterparts in smaller parties. Members of the latter group often need to focus on representing their parties' interests in various parliamentary committees. MPs of large parties are also more credible in promising support for local development. These considerations imply a positive association between party size and constituency focus. On the other hand, politicians in large parties are also well-placed to develop a national focus since they 
are the ones who can actually shape national policies, and therefore one may expect many to embrace the country as the focus of representation. Given that in Hungary the electoral system was twenty years old, while in Romania it was introduced only two years before the empirical study, the size of parties was expected to have a more radically different profile in the former country.

\section{The operationalization of the explanatory variables}

The variables above are captured through largely identical indicators in the two countries, but there are some differences between the Romanian and the Hungarian cases, either due to data availability or to theoretical considerations. As far as the nature of seats is concerned one must take into consideration that Hungary has three tiers: SMD, county list and national list. The three options can be ordered into an ordinal list in terms of how much they bind the MPs to specific geographical regions. The Romanian case is somewhat more difficult to interpret. Every MP is formally tied to an SMD, but the media and the general public often treats those MPs who finished first in their electoral contests (who actually 'won' the contest) differently from those who were second, third, or fourth. Therefore seats will be divided into those won by plurality or absolute majority ${ }^{\text {ix }}$, and those won by fewer votes. The expectation is straightforward: less the seat is associated with particular territory, more the MP will focus on the party (and maybe on the nation) and less on the district. Given that in Romania the differences between seats are more amorphous than in Hungary, we expect a larger impact in the latter country.

As far as the type of candidacy is concerned, in Hungary it is possible to group the MPs into two large blocs: those who were nominated only as list-candidates and those who were also competing in SMD-s In the Romanian case 'list candidature' was not an option, but the candidates could generally anticipate whether they have a better chance to be elected as the winners of an SMD or as beneficiaries of the performance of their party. Two types of indicators were available for this strategic calculation. First, the local elections that took place five months prior to the parliamentary elections provided up-to-date information on the strongholds of the parties. Second, each candidate had information about the likelihood of winning a party mandate based on the size of the population living in the SMD in which he run. The variance in population size matters because in the first phase of the allocation of non-directly won mandates, the candidates of a party in a specific county compete against each other based on the raw number of votes they received and not on the corresponding percentages (Chiru and Ciobanu 2009). Therefore, we operationalize the 'type of candidacy' in Romania by using the population rank of the SMD in which the MP ran, standardized with respect to the number of SMDs in that county. In order to produce an ordinal variable the resulting figures were divided into quartiles.

We hypothesize that candidates nominated in the more densely inhabited SMDs will exhibit a more partisan profile, just like the Hungarian list candidates. The general expectation concerning candidacy is that party-dependent candidates (list-candidates in Hungary and candidates nominated in districts where the likelihood of party mandates were high in Romania) will be party-focused.

One can try to differentiate between the impact of seats versus candidacy not only by entering both variables into a regression analysis, but also by examining politicians who ended up with a non-district seat but who originally ran as SMD-candidates. In Hungary such politicians were 
found to engage more into constituency service and introduce more parliamentary questions on local issues than the list candidates (Montgomery, 1999, p. 514). For Hungary the operationalization is easy: list MPs who originally ran in SMDs versus all the other MPs. In Romania we contrast MPs who had to enter the parliament via the party-backdoor in spite of the fact that they were strong candidates. The latter is operationalized as receiving more than $25 \%$ of the vote.

If it turns out that the Hungarian MPs who ran in SMD districts but obtained list-seats and the Romanian MPs who received their seat via redistribution in spite of the considerable amount of support, are just as district-focused as those who possess SMD seats, then we can conclude that the electoral logic is more relevant than the type of the seat.

Above we assumed that candidacy should matter because it entails different types of campaigning, particularly as far as party-dependency versus personality-focus is concerned. The assumption is plausible, but an examination of the association between campaign style and candidacy status would strengthen our confidence. Fortunately, in the Hungarian case it is possible to gauge more specifically the nature of the campaign. The survey included a battery of questions about how localized, how intensive and how person-centered (as opposed to partycentered) was the campaign. One question specifically asked the MPs whether their campaign aimed at attracting the most attention to their party (0) or to themselves (10).

The rest of the variables have simpler operationalization (see Appendix 1). Parliamentary office is represented by a dummy variable: no office or office at House or committee level. Our 'party office' variable indicates two aspects: whether the MPs has ever had a leadership position in their party and the highest level attained: local, regional or national. The length of party membership is measured through four perfectly even intervals (quartiles). The variable capturing local politics experience has three categories and it reflects how many years one spent as mayor, deputy of the local government or deputy of the county government. The ideological distance between the MP and his party computes the absolute difference between his self-placement on a $0-10$ left-right scale and the mean of the scores assigned to the party by all the respondents belonging to the respective party, on the same scale. All distance scores were re-coded into quartiles so as to avoid empty cells problems when running the multivariate analyses. For party size a dummy variable is used, differentiating large parties: Fidesz, MSZP, PSD and PDL from the rest of the parties. With the partial exception of the PDL, these were the largest parties for most of the post-1989 period.

\section{The dependent variable}

As Table 1 below shows, the parliamentary elites of the two countries have rather different representation roles. Hungarian MPs are more constituency- and country-focused, and less partyoriented. The party focus of the Romanians may be largely due to the fact that the country spent five electoral cycles under closed list PR. One could also speculate that the variation is triggered by the difference in demand for constituency service in the two countries. However, this does not seem to be a plausible explanation given that the 2008 Romanian electoral reform was inspired exactly by the demand for more constituency service (Chiru and Ciobanu 2009).

\section{Table 1 about here}


One may wonder, of course, how valid these answers were. Aren't MPs all partisans, after all? Indeed, just like in most European countries, in Hungary and Romania the legislatures are ruled by parties, displaying high rates of voting cohesion (Ilonszki, 2000; Gherghina and Chiru, 2013). Surely, roll call votes may be misleading as the relevance of diverging roles may materialize in other activities such as lobbying, committee-work, policy-design, constituency work or intraparty politics. Nevertheless before moving to the causal analysis it is important to demonstrate that the answers to the focus of representation question tap consequential attitudes and that the correlates of this question follow theoretical expectations.

Fortunately, both studies asked the MPs: whose opinion should prevail in case of divergence, the party's or one's own? In the Hungarian case a second question followed, one that opposed one's own opinion with that of the voters. The Romanian survey contained questions on the ranking of constituency work versus plenary activities. These questions can help us to establish the validity of the dependent variable. Constituency-focus should go together with valuing the opinion of the voters but not the opinion of the party, and appreciating constituency service more than the plenary activities. Party focus can be expected to characterize those who are ready to yield to the will of the party. As far as the third category, the country-focus is concerned, the expectations are less crystallized. Considering the entire nation as one's principal fits nicely the ideal-typical Burke-an trustee, although one may also regard himself as the delegate of a nation with a united political will. As the first option sounds more plausible, we expect that country-focus will go together with valuing one's own opinion both above the will of the party or of the voters, and focusing on plenary activities as opposed to constituency service.

\section{Table 2 about here}

Table 2 above reports the results of Bonferroni post-hoc pairwise comparisons (based on differences in means). One unexpected finding stands out: party-focused representatives in Romania are particularly likely to perceive constituency service as a salient activity. Otherwise the results point in the expected direction, although not all relationships are significant. District focus indeed implies MPs having a bottom-up orientation: they give more weight to the preferences of the voters than to one's own opinion, disparage plenary activities and reject partyrule (the latter does not reach conventional levels of statistical significance). Party-focused MPs from both countries seem to regard their personal opinion much less consequential than the MPs exhibiting other foci. Country-focus indeed implies a trustee-perception of oneself: those who see the entire nation as their principal take the liberty of going not only against the party but also against the voters. Moreover, their activity is indeed concentrated on the Parliament (plenary work) as opposed to constituency service. While the relationship between focus and various other role-related attitudes is not particularly tight, the validation exercise can be considered successful: the choice of different principals triggers, or at least is related to, meaningfully different attitudes. ${ }^{\mathrm{X}}$

\section{Analysis}

\section{Multivariate explanations}


In order to find out the net effect of the independent variables we entered them into a regression analysis. Because the dependent variable is nominal and has three categories the method deployed was a multinomial logistic regression (Long and Freese 2006). The interpretation of the results considers the relative risk ratios and not the raw estimates. The base outcome is always party focus. Variance inflation factor tests showed that multicollinearity was not a problem for any of the following models.

The Hungarian results (Table 3) confirm that the more territorially bound a seat is the more constituency-focused and less party-focused the MP becomes. Thus, receiving the mandate on the basis of an SMD victory as opposed to being elected from a county list increases by more than three times the likelihood of assuming a constituency-focus compared to a party focus.

Candidacy type is also a significant predictor, and its effect is somewhat larger than that of seat type. Thus, compared to those who participate solely as list candidates, politicians who also run in SMDs are 4.6 times more likely to exhibit a constituency focus. Members of larger parties were less party- and more district-oriented. Ideological distance from the party enhances the partisan focus. Finally, a longer membership record increases the odds of displaying a party focus, although the effect is not particularly large: a move from the smallest quartile to the second smallest quartile doubles the likelihood for a party focus. Thus, the old guard seems to be indeed better socialized into party norms.

Neither the type of seat nor the type of candidacy mattered for the country versus party dilemma. Actually, the only variable that makes a difference is party membership: a longer record facilitates a partisan-focus, as opposed to a country-focus. A switch from the smallest quartile to the second smallest quartile of party membership length makes the Hungarian MPs 2.4 times more likely to embrace a party-focused representation role. In a model not shown here we replaced the type of seat variable with two dummies ('SMD-elected' and 'Elected from county list') and the effects do not change significantly ${ }^{\mathrm{xi}}$. Therefore we chose to keep the more parsimonious model.

\section{Table 3 about here}

In line with our expectations, Romanian MPs who had as candidates a higher chance to win a mandate due to the redistribution of party votes (i.e. a party-dependent type of candidacy) are more likely to embrace a party focus compared to a constituency orientation. More precisely, a switch from the smallest quartile to the second smallest quartile of SMD population-size increased by 1.5 times the likelihood of a party focus.

Candidates who won their SMDs by plurality or majority seem three times more likely to exhibit a party focus as opposed to a country focus. One effect that goes against our hypothesis is that of local politics experience: those MPs who have spent more time in local politics appear less likely to declare a constituency focus compared to a party focus. One possible explanation could be that these politicians do not need to worry too much about the district as they can rely on past record of service and on their connections with local politicians and citizens. Again, similarly to Hungary, higher ideological deviance leads to more party focus, as opposed to country-focus, while belonging to a large party inspired country-focus. 


\section{Table 4 about here}

Holding parliamentary or party office had effect neither in Romania nor in Hungary. Ideological distance from the party, on the other hand, turned out to matter in both contexts. For both Hungarian and Romanian MPs an increase in ideological distance (from the smallest quartile to the second smallest quartile) raises by one and a half times the likelihood of assuming a party focus compared to the district and country alternatives, respectively. This finding goes against the literature-based expectations. The most plausible explanation is that 'constituency men' are non-ideological and therefore place themselves close to the party position. Those who position themselves differently may do so because they are more ideologically minded, and a preference for party focus may characterize the ideologically-minded even if they are outliers in their own party.

Generally, being a member of a large party ${ }^{x i i}$ works against a party-oriented role. The variable's effect is extremely large in Hungary: MPs of the large parties are twenty-nine times more likely to be constituency-oriented. Members of the Romanian large parties are three times more likely to display a national focus than to be party-oriented.

\section{Candidacy as campaign experience}

As discussed above, we expected candidacy type to make a difference primarily due to the different campaign experience. Fortunately in Hungary, where the study was run right after the parliamentary elections, a number of questions directly referred to the campaign, and therefore this assumption can be investigated. The analysis of these questions (not presented here due to space limitations) show that those candidates who canvassed more, organized more rallies in their district, advertised more intensively in local media, and relied more on their personal campaign team in organizing local social events indeed tended to adopt constituency-focus. The constituency-focused candidates were most likely to issue personal posters, buy advertising space in local newspapers and in local electronic media, hold surgeries and publish personal flyers, focus on local issues that were not raised by the party, have their own website and have their own personal campaign team. The Hungarian candidates who had a candidate-centered 'campaign norm' (Zittel and Gschwend 2008) opted, as MPs, for a constituency focus, almost without exception.

\section{Seat versus candidacy}

Finally, we examine the relative influence of the nature of seat and the candidacy type on focus by looking at the attitudes of MPs who could be most torn apart by these two logics. For Hungary we contrasted with the rest of the MPs politicians who gained a list seat although they had also run in SMD (57 MPs). The Cramer's V coefficient showed a moderate association: $.277^{*}$, the analyzed group turned out to be significantly more country- and party-oriented than the rest of the MPs. Only about a quarter (24.6\%) of them were constituency-focused. This result 
confirms Papp (2011) who found that the type of seat is more relevant than the type of candidacy.

In the Romanian case we examined those MPs who failed to gain the plurality of votes but were relatively popular, i.e. gained more than a quarter of votes. Similarly to Hungary, only one of the 13 MPs in this category assumed a constituency representational role, whereas eight of his colleagues declared a party focus.

\section{Table 5 about here}

Table 5 confirms the previous findings with different coefficients. Hungarian SMD-losers ended up with a pronounced preference for party focus and with the rejection of district focus. The Romanian MPs in this group also disparage the district principal. Apparently the district-focused campaign experience has not socialized the politicians into a district focus. The other way around, after learning that they lost the district-seat, they have given up on the local constituencies.

\section{Conclusions}

In the literature of representational roles, the attitudes of politicians are typically explained by their hierarchical positions, their embeddedness in the party or in local politics. Most of the debates concern the question whether these features indicate different ambitions, resources or socialization. In this regard the current study has a negative message, although admittedly limited in terms of the scope for generalization: these factors do not count for much. The only good news for socialization theories is that in Hungary membership length proved to function in the predicted way: it increased party focus. ${ }^{\text {xiii }}$

Party size played a role in both countries. The dramatically strong effect in Hungary may be due to the two decades of experience with the electoral system that taught actors that only candidates of large parties can have a chance of becoming SMD-representatives. This stability of the electoral rules was matched by a relative stability of party sizes. Under such circumstances a division of labor may develop between parties within which it becomes the job of the large parties to think in terms of districts.

Higher ideological distance from the party encouraged partisan focus in both countries. In line with the discussion above, our tentative explanation is that in order to be ideologically deviant first you need to be ideological, and the chances for the later are smaller if you focus on your district.

The Hungarian study, conducted right after the elections, allowed us to illustrate that the various organizational aspects of campaigning are related to the focus of representation. The Romanian study, completed two years after the election, showed that focus makes a difference in terms of prioritizing constituency service versus parliamentary activities, and it does so in a theoretically meaningful way. These relationships and the items on how should an MP behave if in conflict with the party or with the voters, indicated that the focus-question has validity: choosing the district as boss means to be constituency-focused and to follow a delegate style, choosing the 
party implies readiness to accept party discipline, while choosing country indicates a trustee-like role perception.

In both countries the nature of seats (i.e. how territorially bounded they are) was related to the focus of representation as expected: stronger the association, less likely the development of a party- focus (in Hungary) or country-focus (in Romania). The rather large impact of this variable in Romania supports one of the most important findings of the study: the political environment can have almost as much impact on the type of representation as the formal rules.

Similarly, in both countries candidacy type was a significant predictor of the focus of representation as far as the party versus district dichotomy is concerned: those candidates who were more dependent on the party for their election are much more likely to assume a partisan focus.

The perhaps most novel finding of the present study is that serious contenders for SMD seats who end up gaining the mandate thanks to the party become particularly partisan in their role perception. Campaign-circumstances may influence the self-image of the MPs, but a frustrating SMD-campaign may actually 'counter-socialize' the candidates, turning the would-be district ambassadors into committed party delegates.

The study highlighted the relevance of the incentives produced by electoral systems, but also the subtle differences that exist between the electoral and the post-electoral logics of parliamentary politics. As Searing (1994), we note the relevance of position roles, but as opposed to him, we do not find them related to a frontbench-backbench dichotomy but to the expectations of the environment that come with the job. In line with Strøm (1997), the article documented the role of institutional constraints, but, contrary to him, drew the attention to informal institutions, the expectations of the environment, and opened up the explanatory models towards the inclusion of psychological reactions, namely frustration. 


\begin{tabular}{|c|c|}
\hline Variable & Operationalization \\
\hline Representation focus & $1=$ constituency; $2=$ party; $3=$ all citizens $/$ nation \\
\hline Type of seat & $\begin{array}{l}\text { For Hungary: } 1=\text { national, compensation list, } 2=\text { county list, } \\
3=\text { Single Member District. For Romania: } 0=\text { candidate lost } \\
\text { SMD race; } 1=\text { candidate won majority or plurality in SMD. }\end{array}$ \\
\hline Candidacy type & For Hungary: $0=\mathrm{MP}$ who ran only on county and/ or national \\
\hline ('SMD' or not/ SMD & lists. $1=\mathrm{MP}$ ran in SMD and on lists \\
\hline population rank) & $\begin{array}{l}\text { For Romania: } 1=\text { smallest quartile of SMD population rank... } \\
4=\text { highest quartile of SMD population rank }\end{array}$ \\
\hline $\begin{array}{l}\text { Local politics } \\
\text { experience }\end{array}$ & $0=$ no experience $1=$ modest experience $2=$ local politician \\
\hline Ideological distance & $\begin{array}{l}1=\text { smallest quartile... } 4=\text { highest quartile of ideological } \\
\text { distance }\end{array}$ \\
\hline $\begin{array}{l}\text { Party membership } \\
\text { length }\end{array}$ & $\begin{array}{l}1=\text { smallest quartile... } 4=\text { highest quartile of membership } \\
\text { length }\end{array}$ \\
\hline Parliamentary office & $0=$ no office $; 1=$ office at House or committee level \\
\hline Party office & $\begin{array}{l}0=\text { no office; } 1=\text { local leader, } 2=\text { county regional leader, } \\
3=\text { national leader }\end{array}$ \\
\hline Party & $\begin{array}{l}0=\text { small party; } 1=\text { FIDESZ, MSZP (Hungary), PSD, PDL } \\
\text { (Romania) }\end{array}$ \\
\hline
\end{tabular}


Appendix 2: The representativeness of the surveys

Comparison between the MP population and the survey sample (Hungary)

\begin{tabular}{lcccccccc}
\hline & & Incumbent & Women & Fidesz & MSZP & Jobbik & LMP & KDNP \\
\cline { 2 - 9 } MPs & $\%$ & 53.4 & 9.1 & 58.8 & 15.3 & 12.2 & 4.1 & 9.3 \\
\cline { 2 - 9 } Sample & $\%$ & 50.9 & 11.2 & 38.2 & 14.5 & 13.7 & 4.6 & 5.4 \\
\hline
\end{tabular}

Comparison between the MP population and the survey sample (Romania)

\begin{tabular}{lccccccccc}
\hline & & Incumbent & Women & PSD & PUR & PNL & PD & UDMR & Minor. \\
\cline { 2 - 9 } MPs & $\%$ & 37.7 & 11.4 & 32.9 & 0.9 & 19.5 & 34.7 & 6.6 & 5.4 \\
\cline { 2 - 10 } Sample & $\%$ & 32.3 & 11.2 & 27.6 & 0.6 & 28.2 & 31.2 & 7.6 & 4.7 \\
\hline
\end{tabular}




\section{References:}

Andeweg, R.B. and J. Thomassen. (2005) 'Modes of Political Representation: Toward a New Typology', Legislative Studies Quarterly, 30 (4), 507-528.

Batory, A. (2010) 'Europe and the Hungarian Parliamentary Elections of April 2010', EPERN, Election Briefing no. 51.

Bawn, K. and Thies, M.F. (2003) 'A Comparative Theory of Electoral Incentives: Representing the Unorganized Under PR, Plurality, and Mixed-Member Electoral Systems', Journal of Theoretical Politics, 15 (1), 5-32.

Bogdanor, V. (ed.). (1985). Representatives of the people?: parliamentarians and constituents in Western democracies. Aldershot, Hants, England; Brookfield, Vt., USA: Gower.

Carey, J. and Shugart, M. (1995) 'Incentives to Cultivate a Personal Vote: a Rank Ordering of Electoral Formulas', Electoral Studies, 14 (4), 417-439.

Chiru, M. and Ciobanu, I. (2009) 'Legislative Recruitment and Electoral System Change: The Case of Romania', CEU Political Science Journal, 4 (2), 192-231.

Crisp, B.F., Escobar-Lemmon, M., Jones, B., Jones, M.P., Taylor-Robinson, M. (2004) 'VoteSeeking Incentives and Legislative Representation in Six Presidential Democracies', Journal of Politics, 66 (3), 823-846.

Curtice, J. and Shively, P. (2000), 'Who Represents Us Best? One Member or Many?' Centre for Research into Elections and Social Trends, University of Oxford, Working Paper No. 79.

Enyedi, Z. (2010) The 2010 Hungarian Candidate Study. Machine readable data files.

Enyedi, Z. (2014) 'Plebeians, citoyens and aristocrats. Populism in Hungary', in Kriesi, H. and Pappas, T. (eds.) Populism in the Shadow of the Great Recession. ECPR Press, 2014.

Ferrara, F., Herron, E. S., and Nishikawa, M. (2005). Mixed electoral systems: contamination and its consequences. Palgrave Macmillan.

Gallagher, M. and Holliday, I. (2003). 'Electoral Systems, Representational Roles and Legislator Behaviour: Evidence from Hong Kong'. New Zealand Journal of Asian Studies, 5 (1), 107-120.

Gherghina, S. and Chiru, M. (2013) 'Legislative Voting Loyalty after Electoral Reform: Evidence from a New Democracy', International Political Science Review, Online First, September 2013.

Heidar, K. M. and Koole, R. A. (eds.) (2000) Parliamentary Party Groups in European Democracies: Political Parties behind Closed Doors. London, New York: Routledge.

Heitshusen, V., Young, G., and Wood, D.M. (2005) 'Electoral context and MP constituency focus in Australia, Canada, Ireland, New Zealand, and the United Kingdom', American Journal of Political Science 49 (1), 32-45.

Ilonszki, G. (2000) 'Parties and parliamentary party groups in the making: Hungary, 1989-1997', in Heidar, K. M. and Koole, R. A. (eds.), Parliamentary Party Groups in European Democracies: Political Parties Behind Closed Doors. London, New York: Routledge, pp. 214-230.

Jewell, M. E. (1983) 'Legislator-Constituency Relations and the Representative', Legislative Studies Quarterly, 8 (3), 303-337.

Katz, R. S. (1980) A Theory of Parties and Electoral Systems. Baltimore: Johns Hopkins University Press.

Katz, R.S. (1997). 'Representational Roles', European Journal of Political Research, 32 (2), 211-226. 
Long, J. S. and Freese, J. (2006) Regression Models for Categorical and Limited Dependent Variables Using Stata, Second Edition. College Station, Texas: Stata Press.

Lundberg, T. (2002). 'Putting a human face on proportional representation: early experiences in Scotland and Wales'. Representation, 38( 4), 271-283.

Mezey, M. L. (1979) Comparative Legislatures. Durham (NC): Duke University Press.

Montgomery, K. A. (1999) 'Electoral Effects on Party Behavior and Development: Evidence from the Hungarian National Assembly', Party Politics, 5 (4), 507-523.

Norris, P. (1997) 'The puzzle of constituency service', The Journal of Legislative Studies, 3 (2), 29-49.

Olson, D. M. and Norton, P. (2007) 'Post-Communist and Post-Soviet Parliaments: Divergent Paths from Transition', The Journal of Legislative Studies, 13 (1), 164-196.

Papp, Z. (2011) 'Constituency Focus in the Hungarian MPs' Perceptions of Representation', DISC Working Paper Series, No. 21.

Saalfeld, T. and Müller, W. C. (1997) 'Roles in legislative studies: A theoretical introduction', The Journal of Legislative Studies, 3 (1), 1-16.

Searing, D.D. (1994) Westminster's World; Understanding Political Roles, Cambridge Mass: Harvard University Press.

Shugart, M. S. and Wattenberg, M. P. (eds.) (2001) Mixed-member Electoral Systems: The Best of Both Worlds? Oxford, UK: Oxford University Press.

Stefan, L. (2010) Survey of the Romanian Chamber of Deputies. Machine readable data files.

Strøm, K. (1997) 'Rules, reason and routines. Legislative roles in parliamentary democracy. Journal of Legislative Studies, 3 (1), 155-174.

Studlar, D. T. and McAllister, I. (1996). Constituency activity and representational roles among Australian legislators. The Journal of Politics, 58 (1), 69-90.

Tavits, M. (2008) 'On the Linkage between Electoral Volatility and Party System Instability in Central and Eastern Europe', European Journal of Political Research, 47 (5), 537-555.

Zittel, T. (2009) 'Legislators and Their Representational Roles. Rational Calculus or Habits of the Heart?', paper prepared for the Meeting of the DVPW- Section "Comparative Politics", panel 3, Technical University Darmstadt

Zittel T. and Gschwend, T. (2008) 'Individualised Constituency Campaigns in Mixed-Member Electoral Systems: Candidates in the 2005 German Elections', West European Politics, $31(5), 978-1003$.

Wahlke, J.C., Eulau, H., Buchanan, W. and Ferguson, L.C. (1962) The Legislative System: Explorations in Legislative Behavior, Chicago: University of Chicago Press.

Weßels, B. and Giebler, H. (2011) 'Choosing a Style of Representation: The Role of Institutional and Organizational Incentives', paper prepared for presentation at the 6th ECPR General Conference, University of Iceland (25-27 Aug. 2011) 
Table 1: The distribution of representation foci in Hungary and Romania

\begin{tabular}{lll}
\hline & Hungarian MPs & Romanian MPs \\
\hline Constituency & 46.7 & 30.6 \\
Party & 12.8 & 43.6 \\
Country & 40.5 & 25.8 \\
$\mathrm{~N}$ & 222 & 146 \\
\hline
\end{tabular}

Sources: Enyedi (2010); Stefan (2010).

Table 2: Representation foci in relation to various role-related attitudes ${ }^{\mathrm{xiv}}$ - Validation (Bonferroni post-hoc pairwise comparisons)

\begin{tabular}{|c|c|c|c|c|c|c|}
\hline & \multicolumn{3}{|c|}{ Hungarian MPs } & \multicolumn{3}{|c|}{ Romanian MPs } \\
\hline & $\begin{array}{c}\text { District } \\
\text { vs. } \\
\text { others }\end{array}$ & $\begin{array}{l}\text { Party } \\
\text { vs. } \\
\text { others }\end{array}$ & $\begin{array}{c}\text { Country } \\
\text { vs. } \\
\text { others }\end{array}$ & $\begin{array}{c}\text { District } \\
\text { vs. } \\
\text { others }\end{array}$ & $\begin{array}{c}\text { Party } \\
\text { vs. } \\
\text { others }\end{array}$ & $\begin{array}{c}\text { Country } \\
\text { vs. } \\
\text { others }\end{array}$ \\
\hline own opinion (vs. the party) & .001 & -.109 & .053 & .075 & $-.174 * *$ & $.146^{*}$ \\
\hline own opinion (vs. the voters) & $-.111 *$ & -.066 & $.146 * *$ & NA & NA & NA \\
\hline importance of service & NA & NA & NA & .011 & $.201 * *$ & $-.274 * *$ \\
\hline $\begin{array}{l}\text { importance of activity in plenary } \\
\text { sessions }\end{array}$ & NA & NA & NA & $-.456 * * *$ & .099 & $.364 * *$ \\
\hline $\mathrm{N}$ & & $189-19$ & & & $147-15$ & \\
\hline
\end{tabular}

Significance at $* \mathrm{p}<.10 ; * * \mathrm{p}<.05 ; * * * \mathrm{p}<.0$. 
Table 3: Determinants of Representation Foci (multinomial logistic regression) Hungarian MPs.

\begin{tabular}{ll}
\hline & Constituency focus \\
Type of seat & $3.281^{* * *(1.349)}$ \\
Candidacy type ('SMD' or not) & $4.645^{* * *(2.651)}$ \\
Local political experience & $1.081(.381)$ \\
Parliamentary office & $.613(.356)$ \\
Membership length & $.502^{*}(.180)$ \\
Ideological distance & $.654^{*}(.168)$ \\
Party office & $1.039(.311)$ \\
Large Party & $29.376^{* * *(32.895)}$ \\
\hline & Country-focus \\
Type of seat & $1.559(.615)$ \\
Candidacy type ('SMD' or not) & $1.675(.911)$ \\
Local political experience & $1.632(.536)$ \\
Parliamentary office & $1.145(.327)$ \\
Membership length & $.419 * *(.149)$ \\
Ideological distance & $.856(.211)$ \\
Party office & $1.145(.327)$ \\
Large Party & $2.967(2.538)$ \\
\hline McFadden's $\mathrm{R}^{2}$ & .188 \\
$\mathrm{~N}$ & 202 \\
\hline Significance at $*$ p<.10; ** p<.05; $* * * \mathrm{p}<.01$. Cell entries are relative risk ratios; standard errors in \\
parentheses. The base outcome is party focus.
\end{tabular}


Table 4: Determinants of Representation Foci (multinomial logistic regression).

Romanian MPs

\begin{tabular}{ll}
\hline & Constituency-focus \\
Type of seat & $1.328(.766)$ \\
Candidacy type (SMD rank) & $.655^{* *}(.127)$ \\
Local political experience & $.587^{*}(.161)$ \\
Parliamentary office & $1.709(.778)$ \\
Membership length & $.902(.186)$ \\
Ideological distance & $.894(.153)$ \\
Party office & $1.005(.252)$ \\
Large Party & $1.036(.488)$ \\
\hline & Country-focus \\
Type of seat & $.340^{*}(.197)$ \\
Candidacy type (SMD rank) & $.841(.189)$ \\
Local political experience & $1.257(.385)$ \\
Parliamentary office & $2.082(.997)$ \\
Membership length & $.949(.206)$ \\
Ideological distance & $.673^{* *}(.132)$ \\
Party office & $1.047(.328)$ \\
Large Party & $2.878^{* *}(1.323)$ \\
\hline McFadden's $\mathrm{R}^{2}$ & .096 \\
$\mathrm{~N}$ & 145
\end{tabular}

Significance at $* \mathrm{p}<.10 ; * * \mathrm{p}<.05 ; * * * \mathrm{p}<.01$. Cell entries are relative risk ratios; robust standard errors in parentheses. The base outcome is party focus

Table 5: The focus of representation in groups of MPs influenced differently by seat and candidacy (Bonferroni post-hoc pairwise comparisons)

\begin{tabular}{|c|c|c|c|c|c|c|}
\hline & \multicolumn{3}{|c|}{ Hungarian MPs } & \multicolumn{3}{|c|}{ Romanian MPs } \\
\hline & $\begin{array}{c}\text { District } \\
\text { vs. } \\
\text { others }\end{array}$ & $\begin{array}{l}\text { Party } \\
\text { vs. } \\
\text { others } \\
\end{array}$ & $\begin{array}{c}\text { Country } \\
\text { vs. } \\
\text { others }\end{array}$ & $\begin{array}{c}\text { District } \\
\text { vs. } \\
\text { others }\end{array}$ & $\begin{array}{l}\text { Party } \\
\text { vs. } \\
\text { others } \\
\end{array}$ & $\begin{array}{c}\text { Country } \\
\text { VS. } \\
\text { others }\end{array}$ \\
\hline List seat but ran in SMD & $-.234 * * *$ & $.214 * *$ & $.147 * *$ & & & \\
\hline $\begin{array}{l}\text { High share of votes but redistributed } \\
\text { mandate }\end{array}$ & & & & $-.092 *$ & .057 & .028 \\
\hline $\mathrm{N}$ & & 221 & & & 149 & \\
\hline
\end{tabular}

Significance at $* \mathrm{p}<.10 ; * * \mathrm{p}<.05 ; * * * \mathrm{p}<.01$. 
${ }^{\mathrm{i}}$ Carey and Shugart, 1995; Crisp et al, 2004; Katz, 1980, 1997.

ii Bawn and Thies, 2003; Shugart and Wattenberg, 2001; Zittel and Gschwend, 2008; Zittel, 2009.

iii Theoretically one can also run exclusively as SMD candidate, but in reality this almost never happens.

iv Thus, in both cases there were face-to-face contacts between the research teams and the MPs, the only difference being that in Hungary the members of the research teams in most cases read the questionnaire items to the politicians and filled in their answers, whereas in Romania the questionnaires were self-administered and returned to the member of the research team after completion.

${ }^{v}$ Virtually all questions were part of the first-round questionnaire of the Comparative Candidate Survey. For more details see: http://www.comparativecandidates.org/

${ }^{v i}$ Given the extreme centralization in candidate selection and the unusual dominance of the party leader in this process one would expect limited variation of representation foci within Fidesz. However, because since the 2010 election all particular interests need to find their channels to policy makers via Fidesz (Enyedi, 2014), a large variation in the attitudes of the representatives is an equally plausible expectation.

vii The delegate-trustee-politico triad has been shown to have little discriminatory power (Andeweg and Thomassen 2005).

viii The Hungarian question asked: 'Különböző vélemények vannak arról, hogy a parlament választott képviselöi kiket képviseljenek elsősorban. Ön parlamenti munkájában kiket képvisel elsősorban? Kérjük jelölje meg azt, amelyet a legfontosabbnak tekint! Választókerületén belül a saját szavazóit/ Választókerületét/ Pártja választóit/ Egy bizonyos társadalmi csoportot/ Az ország valamennyi állampolgárát.' [There are different opinions about whom an elected member of parliament should primarily represent. Whom do you represent primarily? Own voters in the constituency/ the constituency/ the party electorate at large/ a specific social group/ all citizens of the country.] The Romanian question asked: 'Ca membru al Parlamentului, dvs. vă consideraţi în primul rând un reprezentant al: Partidului dumneavoastră / Alegătorilor dumneavoastră/ Circumscripţiei dumneavoastră/ Întregii ţări/ Unui anumit grup social / Nu ştiu, nu am o preferinţă clară.' ['As member of Parliament you consider yourself first and foremost a representative of: your party/ your voters/ your constituency/ of the entire nation/ of a certain social group/ I don't know, I do not have a clear preference.']

ix Technically the MPs belonging to the second type also receive their seats via redistribution. But they are also "winners" in the sense of receiving most votes and our analysis showed that they are more similar in their representation views to the absolute winners than to their colleagues that ended up second, third or fourth.

${ }^{x}$ T-tests gave virtually identical results - in terms of both statistical significance and direction of the relationships to post-hoc comparisons.

${ }^{x i}$ No other variable acquired or lost statistical significance. An MP who won an SMD mandate appeared 10 times more likely to display a district focus as opposed to a party focus, while someone who got elected from a county list was 7 times more likely to appear district-oriented than party-oriented. The type of seat dummies did not make a difference for the county vs. party dilemma.

${ }^{\text {xii }}$ For most of the cases there are too few observations to run the models separately for each party. However, we did run the models with party dummies. The only additional significant effects can be reduced to the difference between large and small parties, as it was already reflected (through the large party variable) in the models that we present here.

xiii We, of course, do not claim that we managed to capture all manifestations of socialization with our indicators.

xiv The questions on whose opinion should prevail were dichotomous $(1=$ own, $0=$ party or the voters), while the questions on the importance of activities were measured on a 5-grade Likert scale. 